\title{
The description of two new species of testate amoebae from suspended soil of the aerial roots at the tropical urban park in Hainan (China) and the review of the genus Bullinularia Deflandre, 1953 (Amoebozoa: Arcellinida)
}

\author{
Anatoly Bobrov ${ }^{1}$, Natalia Mazei ${ }^{1}$ and Yuri Mazei ${ }^{1,2}$ \\ ${ }^{1}$ Lomonosov Moscow State University, 119991 Moscow, Russia \\ ${ }^{2}$ Severtsov Institute of Ecology and Evolution, 117071 Moscow, Russia
}

| Submitted May 15, 2020 | Accepted June 21, 2020|

\begin{abstract}
Summary
Testate amoeba species composition from the suspended soil of the aerial roots of Ficus sp. and two other biotopes in the Yalong Bay Tropical Paradise Forest Park, Hainan, China is described. Testate amoebae diversity was highest in the suspended soil of the aerial roots (36 taxa) followed by ground soil (25) and litter deposited in the tree hollow (11). Two new species, namely Bullinularia maxima and Bullinularia macroporum, are described as a result of the taxonomic revision of the genus Bullinularia. The key to the species and brief synopsis of the genus Bullinularia is developed.
\end{abstract}

Key words: aerial roots, Bullinularia, Hainan, Plagiopyxidae, suspended soils, testate amoebae, tropical parks

\section{Introduction}

Testate amoebae is a polyphyletic group of unicellular eukaryotes that inhabits a broad range of freshwater, marine and terrestrial biotopes (Chardez, 1965) and attracted many investigators during last decades due to their successful application as bioindicators (Payne 2013). However, some habitats still remain substantially unexplored even though research attention on them frequently reveals previously-unknown testate amoeba communities and new species. Recently we observed such under-studied habitats, e.g. epiphytic, epilithic, and epigenous mosses and lichens (Mazei and Belyakova, 2011;
Payne et al., 2015; Mazei et al., 2016), subterranean deposits (Mazei et al., 2012). Focus of this study is 'suspended soil' (Delamare-Debouteville, 1948), i.e. soil-like deposits accumulated between aerial roots. Suspended soils were shown to contain higher total nitrogen, phosphorus, and potassium contents than the forest soil, but the moisture content in suspended soils is significantly lower (Abakumov et al., 2018). Nevertheless, arboreal habitats harbor high diversity of invertebrates (Paoletti et al., 1991). Testate amoebae in suspended soils have rarely been studied so far (Bamforth, 2007; Krashevska et al., 2010; Potapov et al., 2020).

doi:10.21685/1680-0826-2020-14-3-2 
Our aim is to describe morpho-species diversity within the habitat and to revise the genus Bullinularia, which is characterized by high morphological diversity in a sample. Eight taxa of Bullinularia was described (Meisterfeld, 2008) till now. However, some species are doubtful, and discrete borders are absent within some groups (Meisterfeld, 2008). Despite such complexity, it is crucial for both ecological and molecular studies to have robust criteria for species identification in order to realize morphology based ecological investigations and to help molecular researchers to identify their isolates and supply accurately annotated gene sequences to public databases for phylogenetic analyses (Kosakyan, et al. 2016) as well as to make adequate estimations of ecological preferences (Krashevska et al., 2020).

\section{Material and methods}

The samples were taken on January 5, 2018 in the Yalong Bay Tropical Paradise Forest Park located 25 kilometers southeast from the city Sanya, Hainan, China (coordinates $\left.18^{\circ} 15^{\prime} 16^{\prime \prime} \mathrm{N} 109^{\circ} 38^{\prime} 26^{\prime \prime} \mathrm{E}\right)$. It provides 1,506 hectares of green land in the city. The main area of the park is occupied by a tropical evergreen rain forest. Samples were taken from the suspended soil accumulated between aerial roots of Ficus sp., dangling along the rock surface, on the height ca. $2.0 \mathrm{~m}$ above ground level (Fig. 1, A, B). To compare the diversity with over biotopes we also sampled clay soil on the ground along the stream (Fig. 1, C) and hollow on the trunk of Ficus sp. on the height ca. $0.5 \mathrm{~m}$ (Fig. 1, D).

Samples were kept in a refrigerator before analysis (Mazei et al., 2015). The cells were studied using Motic BA300 (China) and Axioplan 2 (Carl Zeiss, Germany) light microscopes and Jeol 6060 scanning electron microscope.

\section{Results}

1. SPECIES COMPOSITION AND COMPARISON WITH OTHER BIOTOPES

Fifty-five species and subspecific taxa were identified from three samples (Table 1). Suspended soil is characterized by the highest diversity (36 taxa) followed by ground soil (25) and tree hollow (11).
Testate amoeba assemblages in suspended soils are composed by eurybiotic taxa from the genera Centropyxis, Plagiopyxis, Euglypha, and Trinema. In addition, some species from the genera Nebela, Lagenodifflugia, Heleopera, Awerintzevia, which prefer wetter habitats, such as wetlands, were also found here. Moreover, representatives of specific pedobiont group represented by the genera Plagiopyxis, Planhoogenraadia, and Geopyxella dwell in this biotope. All this indicate high local heterogeneity of suspended soils as a habitat. Another peculiar characteristic of the assemblage was high diversity within the genus Bullinularia. We found five different morphotypes within single sample despite the fact that a total of nine species were previously described in this genus (Thomas, 1997; Meisterfeld, 2008).

\section{DESCRIPTION OF SPECIES}

Bullinularia minor (Hoogenraad et de Groot, 1948) Deflandre, 1953 (Figs 2, A-C; 3, E-Q; 5, A)

Description: Shell yellow-brownish, transparent, broadly elliptical, sometimes almost circular, in ventral view (Figs 2, A-C; 3, E-H); ventral surface is smooth with rare siliceous particles; ventral side concaved and forms an apertural cavity (Figs 2, C; 3, G-Q); hemispherical in lateral view (Fig. 3, $\mathrm{J})$; aperture a curving slit in the shape of the young moon in the ventral-aboral view (Figs 2, A-C; 3, $\mathrm{I}, \mathrm{K}, \mathrm{L}, \mathrm{O}-\mathrm{Q}$ ), aperture a straight slit in the ventral view (Fig. 3, E, F); ventral lip of the aperture is thickened and form a rim (Figs 2, B, C; 3, K, N); upper lip with two rows of small pores (Figs 2, A; $3, \mathrm{E}, \mathrm{F})$, upper lip projecting in an outgrowth that slightly covers the apertural funnel and is visible in the view from the side of the visor (Figs 2, B; 3, G, $\mathrm{H}, \mathrm{M})$.

Measurements: shell width (parameter 1 in the Fig. 5, A) - 95-115 $\mu \mathrm{m}$; shell length (parameter 2) - 85-105 $\mu \mathrm{m}$; shell depth $-65 \mu \mathrm{m}$ (see Fig. 3, J); aperture width (parameter 3) $-40-50 \mu \mathrm{m}$.

Comparison with related species: this species is very close to the original description of Bullinularia minor (Fig. 11, A, B), but is slightly larger in size (shell width 77-102 $\mu \mathrm{m}$, shell length 70-83 $\mu \mathrm{m}$ from Hoogenraad and de Groot, 1948); from the species of the same size (Bullinularia gracilis) it is distinguished by its almost circular shape instead of elliptic in B. gracilis. 



Fig. 1. Biotopes sampled for testate amoeba analysis in the Yalong Bay Tropical Paradise Forest Park. A - Aerial roots of Ficus sp.; B - suspended soil accumulated between aerial roots; C - ground soil along the stream; D - hollow on the trunk of Ficus sp.

Bullinularia macroporum Bobrov et Mazei sp. nov. (Figs 3, A-D; 5, B)

Description: Shell yellow-brownish, transparent, circular in ventral view (Fig. 3, A, C); ventral surface is smooth with rare siliceous particles; ventral side concaved and form an apertural cavity (Fig. 3, D); hemispherical in lateral view (Fig. 3, D); aperture a straight slit in ventral view (Fig. 3, A, C); upper lip with one row of very large pores (Fig. 3, A-C), upper lip projecting in an outgrowth that slightly covers the apertural funnel and is visible in the view from the side of the visor (Fig. 3, D).

Measurements: shell width (parameter 1 in the Fig. 5, B) $-110-120 \mu \mathrm{m}$; shell length (parameter 2) $-110-115 \mu \mathrm{m}$; aperture width (parameter 3 ) $-39-42 \mu \mathrm{m}$; diameter of pores on the dorsal lip 7-8 $\mu \mathrm{m}$.

Type locality: Yalong Bay Tropical Paradise Forest Park located 25 kilometers southeast from the city Sanya, Hainan, China (coordinates $18^{\circ} 15^{\prime} 16^{\prime \prime} \mathrm{N}$ $109^{\circ} 38^{\prime} 26^{\prime}$ E); suspended soil accumulated between 

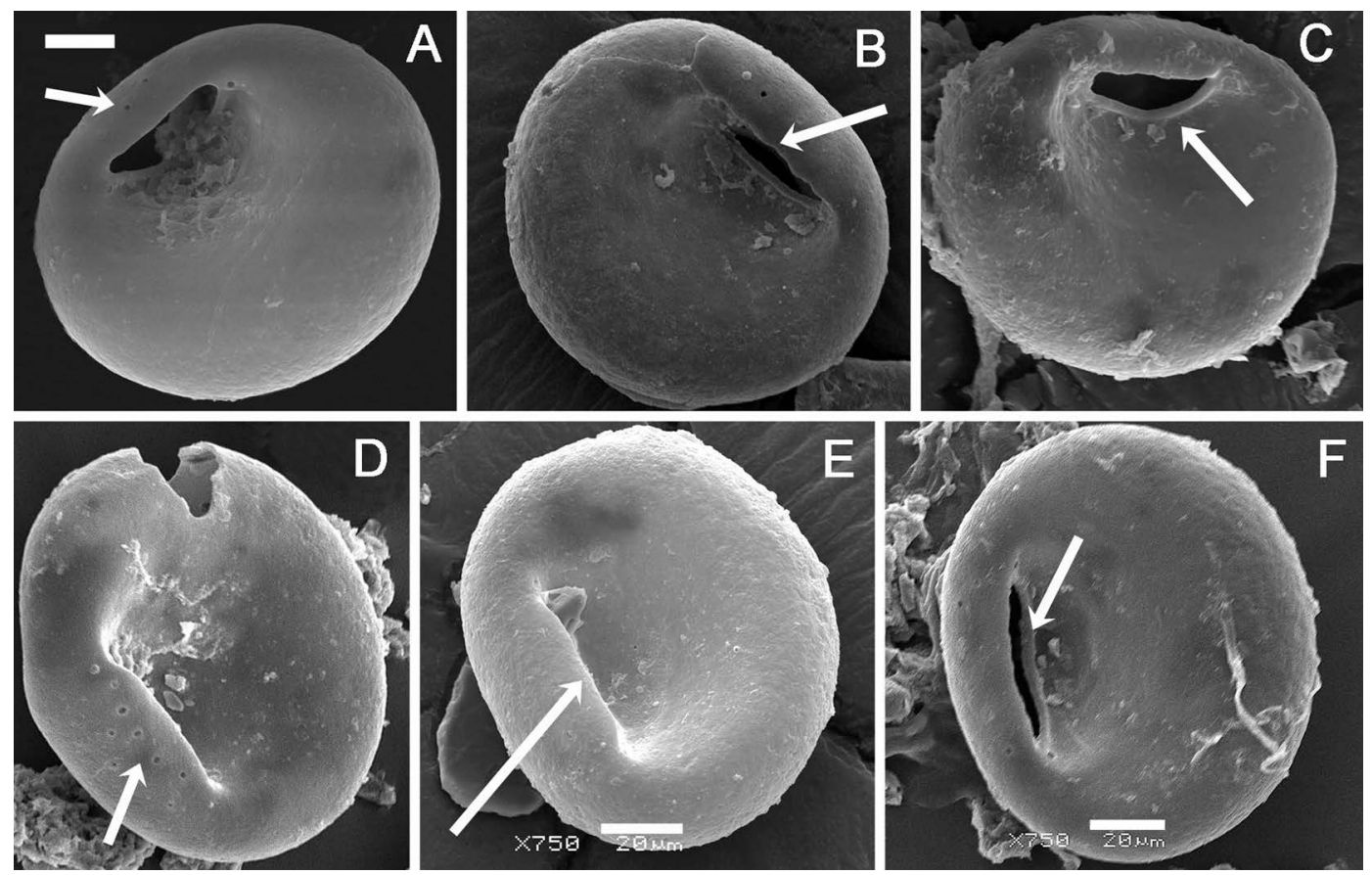

Fig. 2. Scanning electron microscopic images of Bullinularia minor (A-C) and Bullinularia gracilis (D-F). A-C, F - Ventral view slightly from the aboral side (aperture opening is visible); D, E - ventral view from the side of the upper lip. Arrows: A, D - small pores; B, E - upper lip with outgrowth; C, F - the rim of the ventral apertural lip. Scale bar: $20 \mu \mathrm{m}$. Magnification $\times 700(A-D)$ and $\times 750(E, F)$.

aerial roots of Ficus sp., dangling along the rock surface, on the height ca $2.0 \mathrm{~m}$ above ground level.

Type specimen: Laboratory of Soil Bioindication, Department of Soil Geography, Faculty of Soil Science, Lomonosov Moscow State University, slide No. 2-2020.

Etymology: species is named after its most characteristic feature - large pores on the upper lip (from Latin - macros poris).

Comparison with related species: this species is very close to the original description of Bullinularia minor (Fig. 11, A, B), but is larger in size; from the species of the same size (Bullinularia gracilis) it is distinguished by its almost circular shape instead of elliptic in B. gracilis; from all species it differed by presence of large pores on the upper lip.

\section{Bullinularia gracilis Thomas, 1959 (Figs 2, D-F;} $4 ; 5$, C)

Description: Shell brown, transparent, elliptical in ventral view (Figs 2, A-C; 4, A-H); ventral surface is smooth with rare siliceous particles; ventral side concaved and form an apertural cavity (Figs 2, D-F; 4, A-E); aperture is a curved ellipse in the ventral-aboral view (Fig. 4, F-H), aperture as a slightly curved slit in the ventral view (Fig. 4, $\mathrm{B}, \mathrm{C}, \mathrm{E})$; ventral lip of the aperture is thickened and form a rim (Figs 2, F; 4, C, E); upper lip with two rows of small pores (Figs 2, D; 4, A, B, D), upper lip projecting in an outgrowth that slightly covers the apertural funnel and is visible in the view from the side of the visor (Figs 2, D, E; 4, A, D).

Measurements: shell width (parameter 1 in the Fig. 5, C) - 120-135 $\mu \mathrm{m}$; shell length (parameter 2) $-85-100 \mu \mathrm{m}$; aperture width (parameter 3 ) $51-57 \mu \mathrm{m}$.

Comparison with related species: this species is almost identical with the original description of Bullinularia gracilis in terms of size, shape and apertural structures (Fig. 12, A-D). This species is also well compared with third (small and broadly elliptic) form mentioned by Penard (1912).

Bullinularia indica (Penard, 1907) Deflandre, 1953 (Figs 6; 7, A-P; 8, A)

Description: Shell grey-brown, rather transparent, sometimes opaque, broadly elliptical in ventral view (Figs 6, A-C; 7, A-D, G-H, N, P); ventral surface is smooth (Fig. 6, A-C), sometimes covered by siliceous idiosomes (Fig. 6, E, F); dorsal side is 

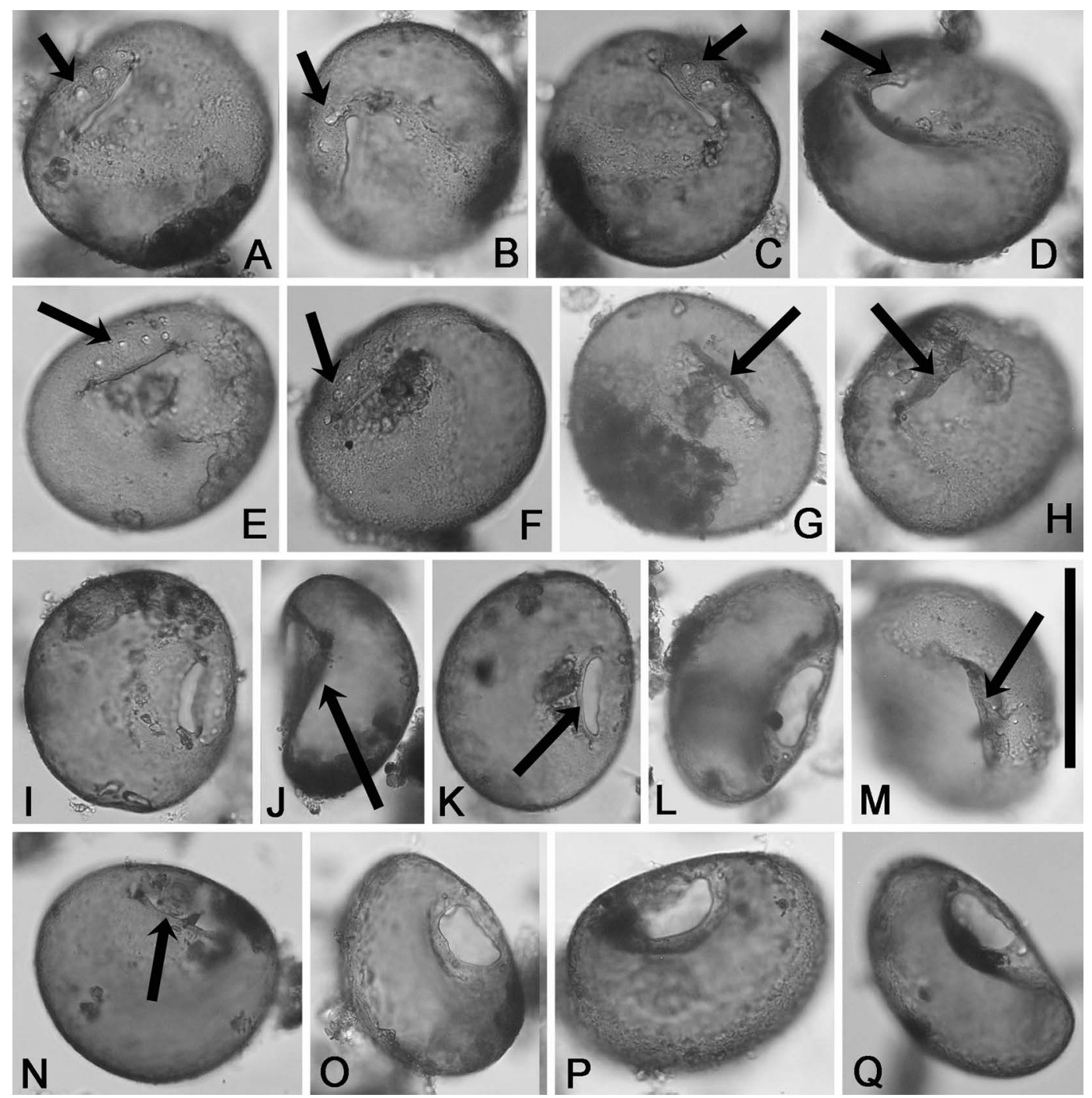

Fig. 3. Light-microscopic images of Bullinularia macroporum (A-D) and Bullinularia minor (E-Q). A-C, E, $\mathrm{F}$ - Ventral view (apertural place as a thin slit); D - ventral-lateral view (apertural cavity and outgrowth of the upper lip are visible); G, H, M - ventral view from the side of the visor (outgrowth of the upper lip is visible); $\mathrm{I}, \mathrm{K}, \mathrm{L}, \mathrm{O}-\mathrm{Q}-$ ventral view from the aboral side (aperture opening is visible); $\mathrm{J}$ - lateral view (apertural cavity is visible); N - aboral view. Arrows: A-C - large pores; E, F - small pores; D, G, H, M - outgrowth of the upper lip; J - apertural cavity; $\mathrm{K}-$ the rim of the ventral apertural lip. Scale bar: $100 \mu \mathrm{m}$. Magnification $\times 700$.

covered by external particles (xenosomes) - Fig. 6, $\mathrm{G}, \mathrm{H}$; ventral side is slightly concaved (Fig. 6, D, E); aperture a slightly curving slit in ventral view (Figs 6, E; 7, A-C, G, H, K-L) and narrow elliptic in the ventral-aboral view (Figs 6, A-C; 7, O); upper lip with two rows of small pores (Figs 6, A-F; 7, A, B, E), upper lip projecting in an outgrowth that covers the apertural funnel and is visible in the view from the side of the visor (Figs 6, D, E; 7, C, D, F-H, $\mathrm{K}-\mathrm{M}, \mathrm{P})$.

Measurements: shell width (parameter 1 in the Fig. 8, A) - 150-165 $\mu \mathrm{m}$; shell length (parameter
2) - 130-140 $\mu \mathrm{m}$; aperture width (parameter 3) 90-95 $\mu \mathrm{m}$.

Comparison with related species: this species has typical appearance in terms of size, shape and apertural structures (Figs 9, C, D; 10, E-I) that currently attributed the name Bullinularia indica (see Penard, 1911, 1912; Cash et al., 1919; Ogden and Hedley, 1980; Geltzer et al., 1995; Todorov and Bankov, 2019).

Bullinularia maxima Bobrov et Mazei sp. nov. (Fig. 7, Q-S) 
Table 1. List of species identified from three biotopes in the Yalong Bay Tropical Paradise Forest Park located 25 kilometers southeast from the city Sanya, Hainan, China.

\begin{tabular}{|c|c|c|c|c|}
\hline \multirow{2}{*}{ № } & \multirow{2}{*}{ Species } & \multicolumn{3}{|c|}{ Biotope } \\
\hline & & suspended soil & ground soil & tree hollow \\
\hline 1 & Arcella arenaria Greef, 1886 & + & - & - \\
\hline 2 & A. arenaria compressa Chardez, 1976 & + & + & - \\
\hline 3 & Bullinularia minor (Hoogenraad et de Groot, 1948) Deflandre, 1953 & + & - & - \\
\hline 4 & B. macroporum Bobrov et Mazei sp. nov. & + & - & - \\
\hline 5 & B. gracilis Thomas, 1959 & + & - & - \\
\hline 6 & B. indica (Penard, 1907) Deflandre, 1953 & + & - & - \\
\hline 7 & B. maxima Bobrov et Mazei sp. nov. & + & - & - \\
\hline 8 & Trigonopyxis arcula Penard, 1912 & + & - & - \\
\hline 9 & Centropyxis aculeata (Ehrenbeg, 1838) Stien, 1857 & + & + & - \\
\hline 10 & C. aculeata dentistoma Decloitre, 1951 & - & + & - \\
\hline 11 & C. acuminata Couteaux et Chardez, 1981 & - & + & - \\
\hline 12 & C. aerophila Deflandre, 1929 & - & + & - \\
\hline 13 & C. aerophila cornata Decloitre, 1978 & + & - & + \\
\hline 14 & C. aerophila minuta Chardez 1964 & + & + & - \\
\hline 15 & C. cassis (Wallich, 1864) Deflandre, 1929 & + & - & - \\
\hline 16 & C. constricta (Ehrenberg, 1841) Deflandre, 1929 & - & + & - \\
\hline 17 & C. constricta v. minuta Decloitre, 1953 & + & + & - \\
\hline 18 & C. delicatula Penard, 1902 & + & - & + \\
\hline 19 & C. elongata cf. minor & - & + & - \\
\hline 20 & C. plagiostoma Bonnet et Thomas, 1955 & + & - & - \\
\hline 21 & C. cf. plagiostoma & - & + & - \\
\hline 22 & Centropyxis sp. 1 & + & - & - \\
\hline 23 & Centropyxis sp. 2 & - & - & + \\
\hline 24 & Cyclopyxis eurystoma Deflandre, 1929 & - & + & + \\
\hline 25 & C. eurystoma parvula Bonnet et Thomas, 1960 & + & + & + \\
\hline 26 & C. kahli Deflandre, 1912 & - & + & - \\
\hline 26 & C. kahli cyclostoma Bonnet et Thomas, 1960 & - & + & - \\
\hline 28 & C. cf. kahli & - & + & - \\
\hline 29 & Plagiopyxis declivis Bonnet, 1955 & + & - & - \\
\hline 30 & P. minuta Bonnet, 1959 & + & + & - \\
\hline 31 & P. penardi Thomas, 1955 & - & + & - \\
\hline 32 & Plagiopyxis sp. & + & - & - \\
\hline 33 & Planhoogenraadia media Bonnet, 1979 & - & - & + \\
\hline 34 & P. cf. wuhanica Bobrov et al., 2019 & - & + & - \\
\hline 35 & Awerintzevia cyclostoma (Penard, 1902) Schouteden, 1906 & + & + & - \\
\hline 36 & Geopyxella sylvicola Bonnet et Thomas, 1955 & - & + & - \\
\hline 37 & Heleopera minuta Decloitre, 1966 & + & - & - \\
\hline
\end{tabular}


Table 1. Continuation.

\begin{tabular}{|c|c|c|c|c|}
\hline \multirow{2}{*}{ № } & \multirow{2}{*}{ Species } & \multicolumn{3}{|c|}{ Biotope } \\
\hline & & suspended soil & ground soil & tree hollow \\
\hline 38 & H. sylvatica Penard, 1890 & + & + & - \\
\hline 39 & Nebela militaris Penard, 1890 & + & - & - \\
\hline 40 & Nebela sp. & + & - & -- \\
\hline 41 & Padaungiella wailesi (Deflandre, 1936) Lara et Todorov, 2012 & + & - & - \\
\hline 42 & Phryganella microps Valkanov, 1963 & + & - & - \\
\hline 43 & Difflugia lucida Penard, 1890 & + & - & - \\
\hline 44 & Lagenodifflugia vas (Leidy, 1874) Medioli et Scott, 1983 & + & - & - \\
\hline 45 & Tracheleuglypha acolla Bonnet et Thomas, 1955 & + & - & - \\
\hline 46 & Assulina muscorum Greeff, 1888 & - & - & + \\
\hline 47 & Euglypha ciliata (Ehrenberg, 1848) Leidy, 1878 & + & - & - \\
\hline 48 & E. cristata decora Jung, 1942 & - & - & + \\
\hline 49 & E. cuspidata Bonnet, 1959 & + & + & - \\
\hline 50 & E. laevis Perty, 1849 & + & + & + \\
\hline 51 & Trinema complanatum Penard, 1890 & - & - & + \\
\hline 52 & T. enchelys (Ehrenberg, 1938) Leidy, 1878 & - & + & - \\
\hline 53 & T. lineare Penard, 1890 & + & + & + \\
\hline 54 & T. lineare minuscula Chardez, 1968 & + & - & - \\
\hline 55 & T. lineare terricola Decloitre, 1962 & + & - & - \\
\hline \multicolumn{2}{|c|}{ NUMBER OF TAXA } & 36 & 25 & 11 \\
\hline
\end{tabular}

Description: Shell brown, opaque, elliptical in ventral view (Fig. 7, Q-S); ventral surface is covered by external particles (xenosomes) - Fig. 7, Q-S; aperture a eight-shaped slit; upper lip projecting in a large concaved outgrowth that covers the apertural funnel and is visible in the ventral view (Fig. 7, Q-S).

Measurements: shell width (parameter 1 in the Fig. 8, B) - 205-220 $\mu \mathrm{m}$; shell length (parameter 2) $-160-170 \mu \mathrm{m}$; aperture width (parameter 3) $100-120 \mu \mathrm{m}$.

Type locality: Yalong Bay Tropical Paradise Forest Park located 25 kilometers southeast from the city Sanya, Hainan, China (coordinates $18^{\circ} 15^{\prime} 16^{\prime \prime N}$ $109^{\circ} 38^{\prime} 26^{\prime \prime} \mathrm{E}$ ); suspended soil accumulated between aerial roots of Ficus sp., dangling along the rock surface, on the height ca $2.0 \mathrm{~m}$ above ground level

Type specimen: Laboratory of Soil Bioindication, Department of Soil Geography, Faculty of Soil Science, Lomonosov Moscow State University, slide No. 3-2020.

Etymology: species is named after its most characteristic feature - large size (from Latin maximus).
Comparison with related species: this species fit well in size (shell width ca. $200 \mu \mathrm{m}$ ) and elliptical shell shape with the first description of Bullinularia indica (see Penard, 1907 and Fig. 10, A) and clearly different from smaller form, which is already named here as $B$. indica following an established tradition. We suggest to rename this morphotype despite the priority of first description name to keep stability in the field. It is time to legalize the differences between two forms of Bullinularia indica stated already in 1911 by Eugene Penard.

\section{Discussion}

\section{BRIEF SYNOPSIS OF THE GENUS}

Genus Bullinularia Deflandre, 1953 is characterized by ovoid or circular in front view shell with flattened or bellied ventral surface. Slit-like aperture is eccentric, invaginated, completely or partially hidden by the upper (dorsal) apertural lip (cryptostome life form). A key character is the pores 

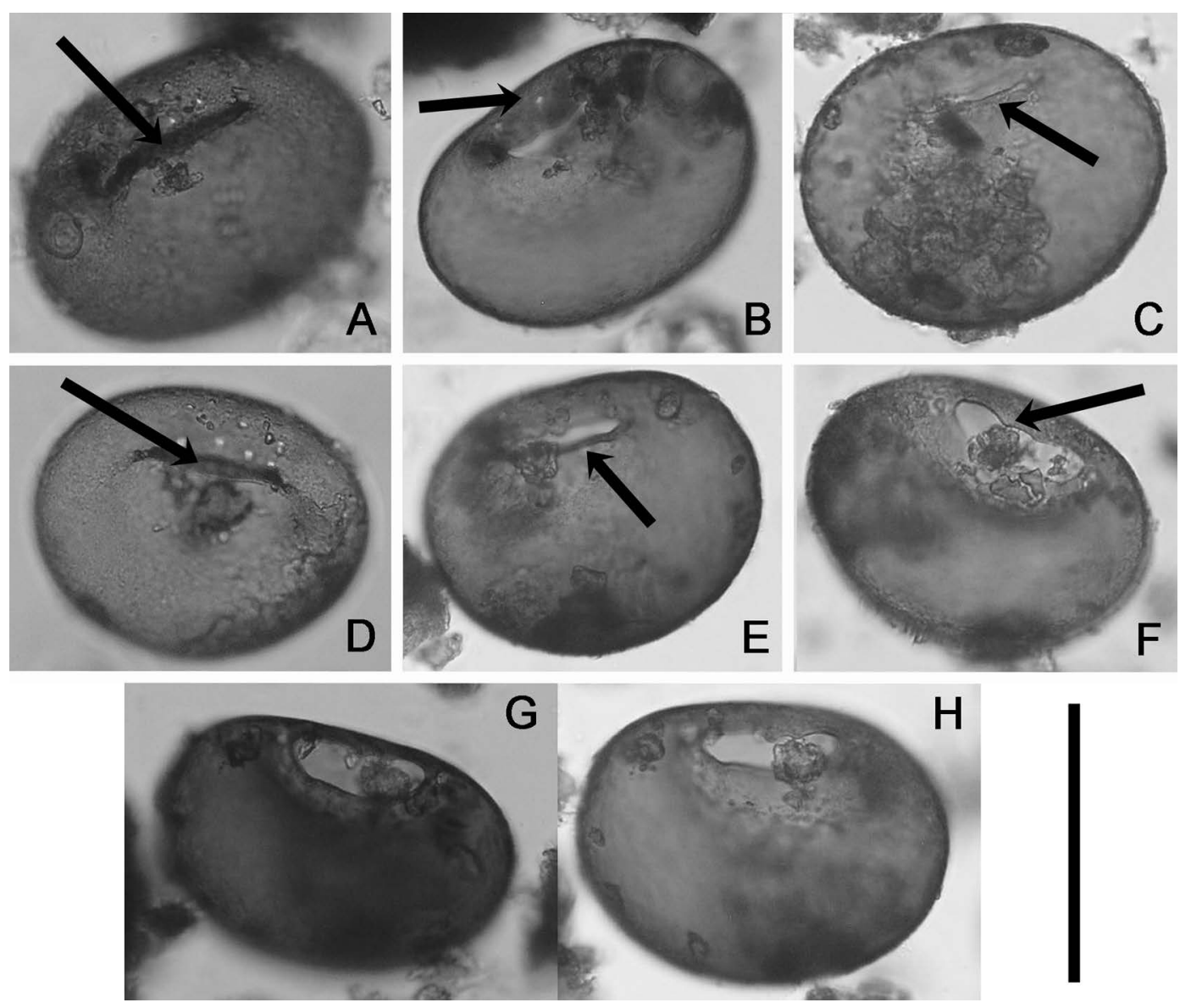

Fig. 4. Light-microscopic images of Bullinularia gracilis. A, D - Ventral view from the side of the upper lip (apertural opening is not visible, outgrowth of the upper lip is visible); B, E-H - ventral view from the aboral side (apertural opening is visible); $\mathrm{C}-$ ventral view (apertural place as a thin slit). Arrows: A, D, F - outgrowth of the upper lip; B - small pores; C, E - the rim of the ventral apertural lip. Scale bar: $100 \mu \mathrm{m}$. Magnification $\times 200$.

on the upper lip, on the apex and, depending on the species, on the ventral side. Nine species were described under the generic name Bullinularia so far (Fig. 9).

First species was described by Eugene Penard in 1907 (Fig. 10, A-D) from the moss samples of Sikkim Himalaya under the name Bulinella indica (Penard, 1907). Newly erected genus Bulinella was described as having shell pierced on the ventral face by an elongate narrow slit (aperture) with a smooth interior lip and over-hanging superior lip pierced with pores (Fig. 10, A). Bulinella indica is characterized by an elliptical shell, brownish, covered by numerous siliceous particles that are smaller in the buccal region; the aperture is a long narrow slit in the tangential direction, with an inferior lip which by its convex anterior border is prolonged a little forward, and a superior lip of irregular or undulate outline, which projects over the inferior lip (Fig. 10, B, C); rounded pores, 2-3 $\mu \mathrm{m}$ in diameter, disposed in unequal series all over the upper lip (Fig. 10, D); greatest diameter of the shell, i.e. shell width, is $160-200 \mu \mathrm{m}$ (Note: in the species diagnosis E. Penard (1907, p. 277) indicated shell width $170-200 \mu \mathrm{m}$, however in the introductory section (Penard, 1907, p. 274) he indicated shell width 160-200 $\mu \mathrm{m}$ ), anterio-posterior diameter (shell length) is $120-140 \mu \mathrm{m}$. This description fits well with the largest morphotype in our study which we propose to transfer into the new species, B. maxima, to keep the common name to the smaller morphotype (see below).

In 1911 Eugene Penard described other findings of this species (Penard, 1911) from different regions and noted that some findings fitted well with an original description from the Himalayan population, but one moss sample from Uganda contained both considerably larger (shell width 190-250 $\mu \mathrm{m}$ ) 


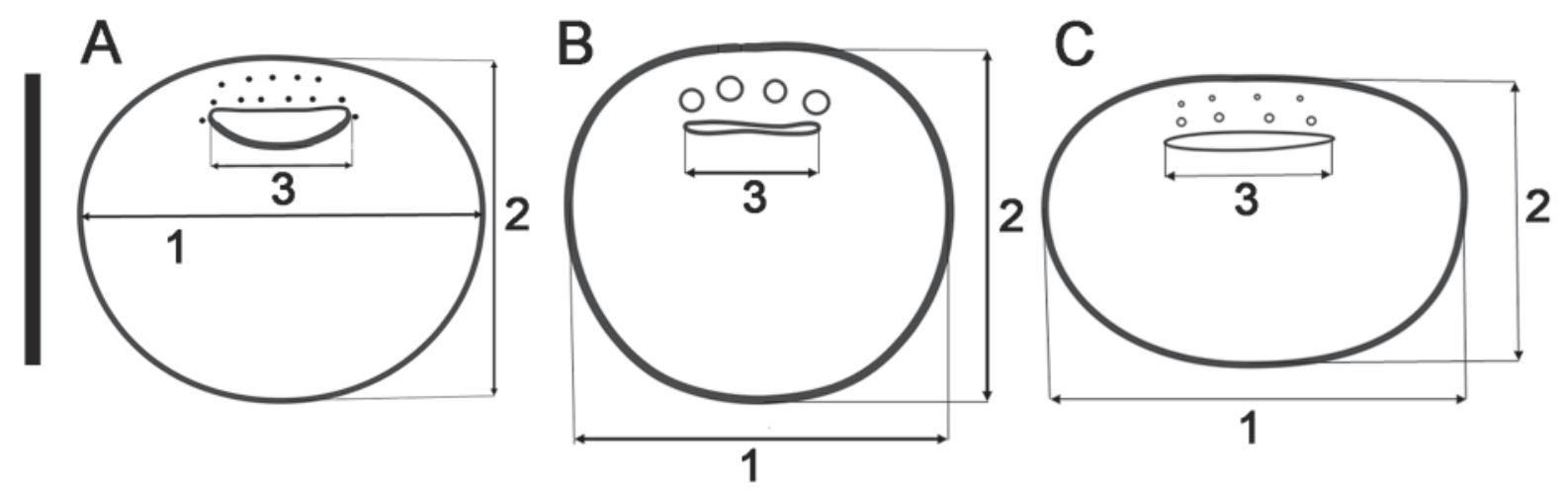

Fig. 5. Outlines of the ventral views with visible apertures of Bullinularia minor (A), Bullinularia macroporum (B), Bullinularia gracilis (C). 1-3 - Characters of the shell measurements. Scale bar: $100 \mu \mathrm{m}$.

organisms with elliptical shells, and considerably smaller (shell width 130-170 $\mu \mathrm{m}$ ) with circular shells (Fig. 10, E). He found such different size forms in the samples all over the world, stressed that these forms are connected by numerous transitions, and noted, that the small form might be considered as variety but didn't erect it formally. Nevertheless, some authors (Bartoš, 1940, 1954; Mazei and Tsyganov, 2006, and others) have used the name $B$. indica var. minor Penard, 1911, which is formally must be considered as a nomen nudum (Meisterfeld, 2008).

Moreover, in this paper (Penard, 1911) E. Penard mistakenly proposed that Bulinella was a preoccupied name for a mollusc (however, Bulinella was an incorrect spelling of Bullinella Newton, 1891) and replaced the correct name he created in 1907 by a homonym, i.e. Bullinula. Although Bulinella Penard, 1907 is a valid name, it has not been in use since original description. Moreover, G. Deflandre (1953) erected a new name for the taxon, i.e. Bullinularia, that was extensively used afterwards. Thus, generic name Bullinularia Deflandre, 1953 should be kept for reasons of stability (Meisterfeld, 2008).

In 1912 E. Penard (Fig. 10, F, G) stated that in some locations the smaller form replaces the type completely while in other places where they occur together, they are not connected by any transitions (Penard, 1912). He also mentioned a third very broadly elliptic small size form (shell width 120-125 $\mu \mathrm{m})$ with transparent shells. In this paper we propose to consider this form as Bullinularia gracilis.

Several years later Cash et al. (1919) reported $B$. indica as common species with ellipsoidal shell (Fig. $10, \mathrm{H}, \mathrm{I})$, dark brown, flattened or concave on the ventral or buccal face, composed of a thin covering of small siliceous grains and plates; aperture long, arcuate, narrow, with the inner lip prolonged and incurved, the outer lip usually furnished with a row of pores; shell width 120-250 $\mu \mathrm{m}$ (but in the British Isles usually $140-180 \mu \mathrm{m}$ ), length of aperture equal to about half the greater diameter of the test (shell width); pores on outer lip $2-3 \mu \mathrm{m}$ in diameter, vary in number and in their disposition, and occasionally cannot be distinguished.

Bartoš (1938) also described high variability of $B$. indica from different samples with shells ranged from smallest elliptic forms $(100-122 \mu \mathrm{m}$ width and 83-89 $\mu \mathrm{m}$ length) to larger organisms with shell width 150-235 $\mu \mathrm{m}$ and shell length 134-184 $\mu \mathrm{m}$. Wherein, among this size range he noted circular and elliptic shells including those elongated in both directions, parallel to the slit and perpendicular to it. Smallest elliptic form is most likely corresponding with B. gracilis (see below). Whereas larger forms also identified as $B$. indica in recent monographs with the shell width 133-213 $\mu \mathrm{m}$ and shell length 122-175 $\mu \mathrm{m}$ (Ogden and Hedley, 1980; Delaine et al., 2017; Todorov and Bankov, 2019). Nevertheless, in some cases two size groups are still distinguished (Delaine et al., 2017). We suggest to split this high variable group of taxa into two: Bullinularia maxima with largest, more than $200 \mu \mathrm{m}$ in width, elliptic shells (corresponding to original description of Penard, 1907); and smaller, broadly elliptic to circular shells, 130-200 $\mu \mathrm{m}$ in width (corresponding to smaller from distinguished by Penard, 1911) and keep for it the name Bullinularia indica as it is better fit with the most of the $B$. indica descriptions made through the century of its investigation (Ogden and Hedley, 1980; Delaine et al., 2017; Todorov and Bankov, 2019). We understand that there are no distinct clear-cut morphological and morphometrical 

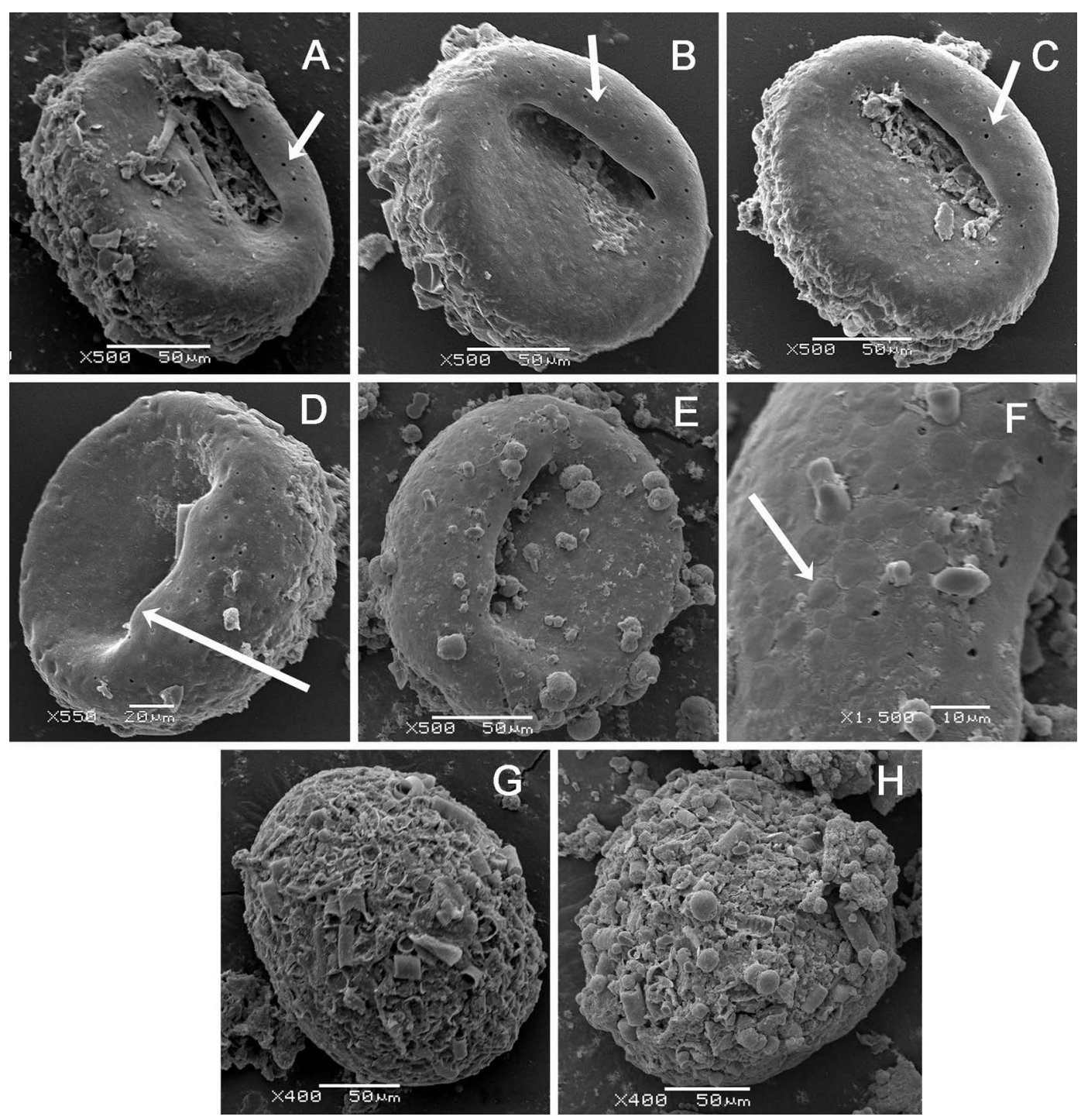

Fig. 6. Scanning electron microscopic images of Bullinularia indica. A-C - Ventral view slightly from the aboral side (aperture opening is visible); D, E - ventral view from the side of the upper lip; F - upper lip with pores and idiosomes; G, H - dorsal view. Arrows: A-C - small pores; D, E - the outgrowth of the upper lip; $\mathrm{F}$ - idiosomes.

borders between two species and we rather see the extremes of the continuum. This continuum should be studied in more details by means of molecular (Kosakyan et al., 2012; Heger et al., 2013) and ecological (Krashevska et al., 2020) approaches in order to reveal fine peculiarities in gene structures and environmental preferences to have additional information for species delimitation.

In his survey of the genus Bullinularia R. Meisterfeld (2008) subdivided all the diversity of previously described taxa into three size classes.

The smallest size class include B. minor Hoogenraad et de Groot, 1948 (Fig. 9, K), B. pulchella
Schönborn, 1964 (Fig. 9, L), and B. navicula Bonnet, 1979 (Fig. 9, J).

Hoogenraad and de Groot (1948) described new taxon, B. minor, from the New Zealand (and also reported from USA) samples, which is distinguished from the type species by its smaller size (shell width $77-102 \mu \mathrm{m}$, shell length $70-83 \mu \mathrm{m}$ ), broadly elliptic to circular outline in the ventral view, smooth surface, not opaque shell (Fig. 11, A, B). Apertural area is similar to those in $B$. indica, i.e. the cleft of the aperture in vertical projection showed itself narrow elliptical with undulating margins, upper and under lip normally developed with a thickened and 

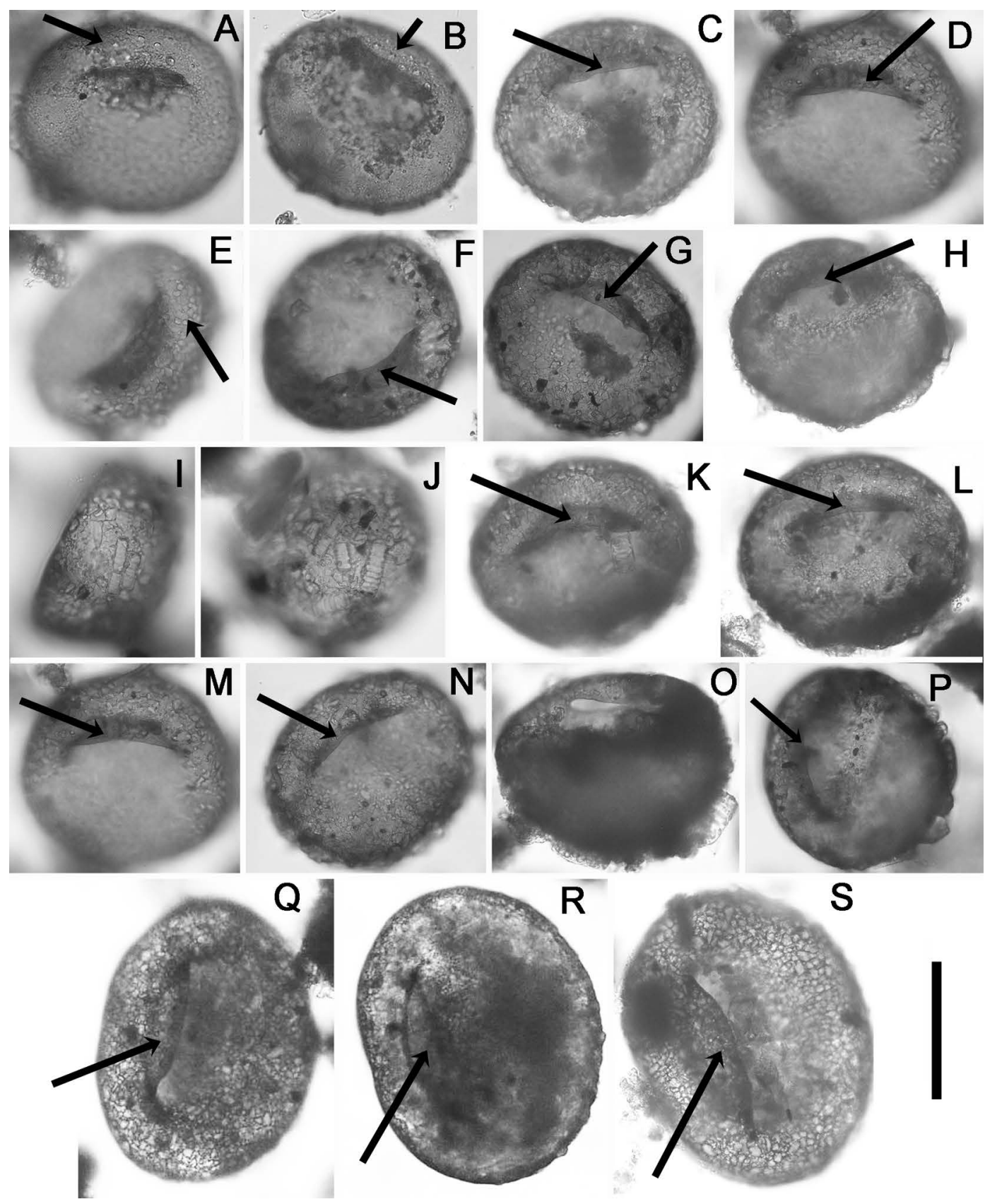

Fig. 7. Light-microscopic images of Bullinularia indica (A-P) and Bullinularia maxima (Q-S). A, B - Ventral view (apertural place as a thin slit; microscope focused on the slit); $-\mathrm{H}, \mathrm{K}-\mathrm{N}, \mathrm{Q}-\mathrm{S}-$ ventral view from the side of the upper lip (apertural opening is not visible, outgrowth of the upper lip is visible); I - lateral view; J dorsal view; $\mathrm{O}$ - ventral view from the aboral side (apertural opening is visible); $\mathrm{P}$ - ventral view from slightly lateral and aboral sides (outgrowth of the upper lip is not so prominent). Arrows: A, B, E-small pores; C, D, $\mathrm{F}-\mathrm{H}, \mathrm{K}-\mathrm{N}, \mathrm{P}-\mathrm{S}-$ outgrowth of the upper lip. Scale bar: $100 \mu \mathrm{m}$. Magnification $\times 200$.

darker colored rim, the upper lip often projecting in a triangular tip. Bartoš (1963) illustrated this taxon (Fig. 11, C-E) from moss samples taken at the Guandong province, China and stressed small size (shell width $87-100 \mu \mathrm{m}$, shell length $80-81$ $\mu \mathrm{m})$ and prominent dark projection of the upper lip (Fig. 11, D, E).

Schönborn (1964) distinguished B. pulchella (Fig. 11, F) that differed from other taxa by its small size (shell diameter 70-72 $\mu \mathrm{m}$ ). However, 

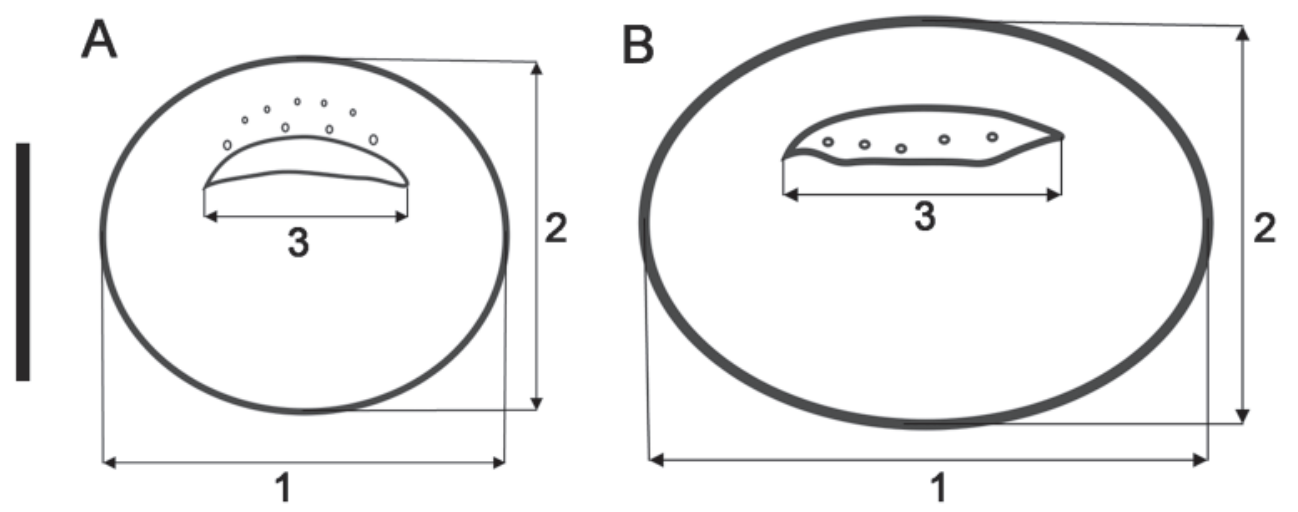

Fig. 8. Outlines of the ventral views of Bullinularia indica (A) and Bullinularia maxima (B). 1-3 - Characters of the shell measurements. Scale bar: $100 \mu \mathrm{m}$.

he mistakenly noted that $B$. minor has dimensions $163 \mu \mathrm{m}$. In fact, this taxon does not separable from B. minor, and Meisterfeld (2008) synonymized $B$. pulchella with B. minor.

Bonnet (1979) erected B. navicula (Fig. 11, G-I) from tropical forests soil which is characterized by small size (average shell width $88.6 \mu \mathrm{m}$, average shell length $51.5 \mu \mathrm{m}$ ) centrally placed slit-like aperture and upper lip in a shape of circular arc projection as a "chitinoid" tongue penetrating fairly deeply and cover apertural cavity. Bonnet (1979) definitely noted that no pores on the upper lip were observed. Assuming that presence of pores on the upper lip is a diagnostic character of the genus, Meisterfeld (2008) transferred this species into the genus Plagiopyxis. However, only 7 speciemns were observed by Bonnet (1979), and taking into the account that pores are can easily be overlooked in the specimens densely covered by xenosomes (Cash et al., 1919), we can underline that further studies needed to clarify the taxonomic status of this species.

Thomas (1997) described another small size (shell width 65-95 $\mu \mathrm{m}$, shell length 55-72 $\mu \mathrm{m}$ ) form, Bullinularia champi, from Nepal (Fig. 11, $\mathrm{J}-\mathrm{N}$ ) with irregural shape of croissant-like aperture. Unfortunately, pores on the dorsal lip are not described and the nature of aperture shape variability is not clear neither from the description, nor from the drawings. We suggest to consider this species as a synonym of $B$. minor.

The intermediate size group is formed by $B$. devexa Coûteaux et Munsch, 1978 (Fig. 9, F, G), B. gracilis Thomas, 1959 (Fig. 9, H, I), and a small form of $B$. indica. The classification of these taxa is not very clear (Meisterfeld, 2008).
Bullinulariagracilis (Fig. 12, A-D) was described by Thomas (1959) and well compared with third (small and broadly elliptic) form mentioned by Penard (1912): the shell width is $120-125 \mu \mathrm{m}$, elliptic in ventral view, transparent, surface is smoth and covered by very rare xenosomes, upper lip projecting in a triangular tip. Golemansky (1966) provided micrograph of this species (Fig. 12, E) and reported slightly larger size, i.e. shell width $133.5 \mu \mathrm{m}$, shell length $106.7 \mu \mathrm{m}$, whereas other characters are very similar with the description of Thomas (1959). In two years Golemansky (1968) identified as B. gracilis even larger specimen (Fig. $12, \mathrm{~F})$ with shell width $150 \mu \mathrm{m}$ and shell length 110 $\mu \mathrm{m}$. Lüftenegger and Foissner (1991) also illustrated a population (Fig. 12, G, H), which is $25 \%$ larger than original description by Thomas (1959) with shell width $128-192 \mu \mathrm{m}$ (average $150 \mu \mathrm{m}$ ) and shell length 112-169 $\mu \mathrm{m}$ (average $130 \mu \mathrm{m}$ ). The opposite tendency is to lump B. gracilis Thomas, 1959 with B. minor Hoogenraad et de Groot, 1948, as it was proposed by Bartoš (1963). We suggest here to not enbroad original description of $B$. gracilis and limit shell width range between 120-135 $\mu \mathrm{m}$ and lump larger forms, described by Golemansky (1968) and Lüftenegger and Foissner (1991) with Bullinularia indica.

Bullinularia devexa (Fig. 12, I, J) was erected by Coûteaux and Munsch (1978) from litter, soil and rhizosphere of epiphytes in mangrove (Guadalupe) and characterized by elliptical shell in ventral view; dorsal side domed, ventral side sloping with ventral lip of pseudostome with a thickened border, and concealed by a curved, sometimes scalloped, dorsal lip, pierced with several pores randomly arranged; aperture mostly with the corners in the shape of 

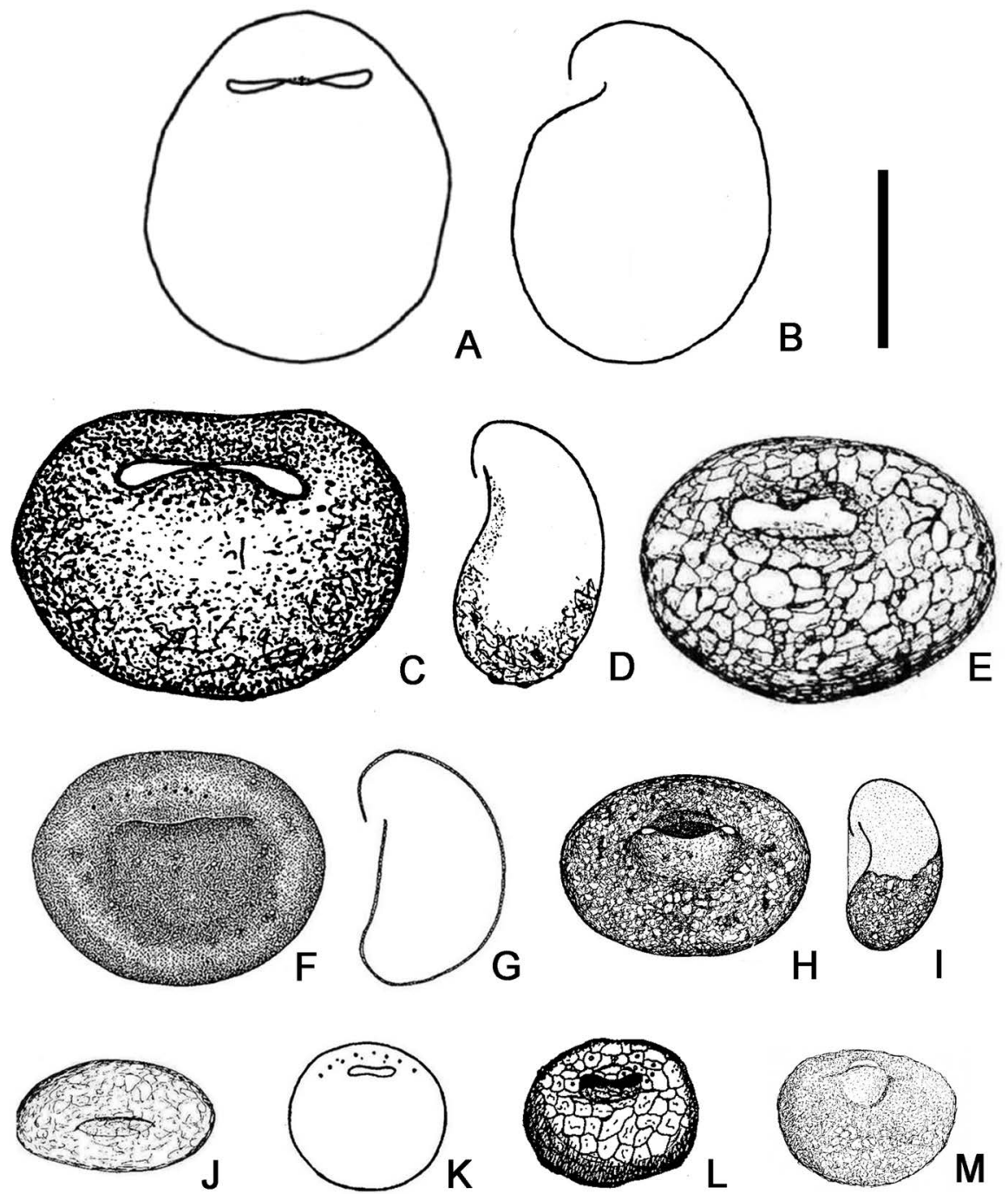

Fig. 9. Different species that ever been named Bullinularia. A, B - B. foissneri (after Meisterfeld, 2008); C, D B. indica (after Geltzer et al., 1995); E - B. lithophora (after Bonnet, 1974); F, G - B. devexa (after Coûteaux and Munsch, 1978); H, I - B. gracilis (after Bonnet and Thomas, 1960); J - B. navicula (after Bonnet, 1979); K - B. minor (after Hoogenraad and de Groot, 1948); L - B. pulchella (after Schönborn, 1964); M - B. champi (after Thomas, 1997). A, C, E, F, H, J-M - Ventral views; B, D, G, I - lateral views. Scale bar: $100 \mu \mathrm{m}$.

an eight; shell very dark and opaque, surface fairly smooth; shell width 124-170 $\mu \mathrm{m}$ (median 162 $\mu \mathrm{m})$, shell length 97-149 $\mu \mathrm{m}$ (median $137 \mu \mathrm{m})$. Neither in the original description (Coûteaux and Munsch, 1978), nor in the comparative table prodused by Meisterfeld (2008) distinct characters that separate the two species $B$. devexa from $B$. indica are indicated. Therefore $B$. devexa is considered as a synonym of $B$. indica.

Small form of Bullinularia indica, distinguished by Penard $(1911,1912)$ is also included in this group. However, as it was noted by Meisterfeld (2008) delimination between all taxa are unclear due to considerable overlapping in shell size and not identified clear morphological features of strong taxonomic value. Thus, as it is state above, we keep for this small form of Bullinularia indica this name, synonimize $B$. devexa with $B$. indica and keep independence of $B$. gracilis.

The largest size group contain the form of Bullinularia indica described by Penard (1907) and transferred in this work to Bullinularia maxima (Figs 7, G-S; 8, B; 10, A), Bullinularia lithophora described by Bonnet (1974) - Fig. 12, K, and Bullinularia foissneri described by Meisterfeld (2008) - Fig. 9, A, B. Bullinularia lithophora is characte- 

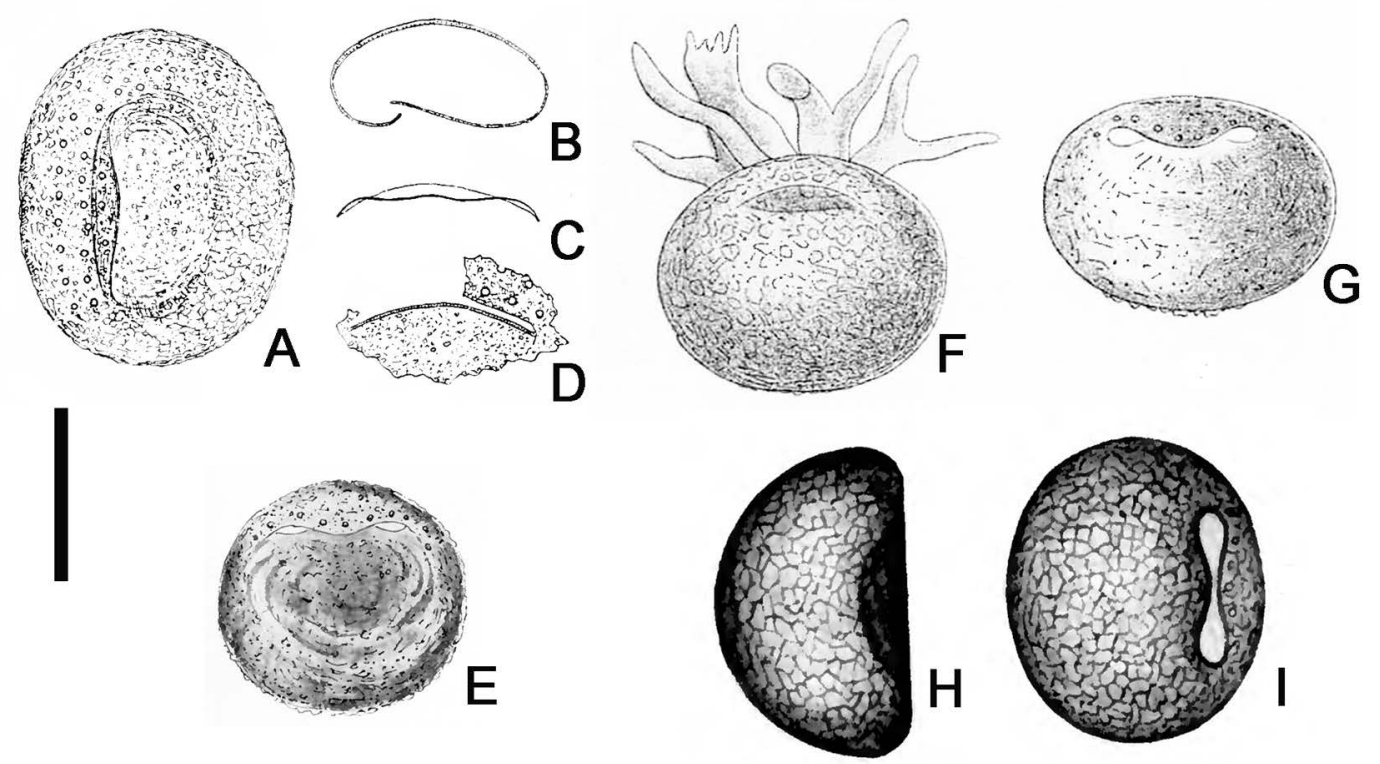

Fig. 10. Bullinularia indica. A, E, G, I - Ventral view; B, H - lateral view; F - dorsal view; C, D - details of the aperture. A-D - After Penard, 1907; E - after Penard, 1911; F, G - after Penard, 1912; H, I - after Cash et al., 1919. Scale bar: $100 \mu \mathrm{m}$.

rized by colorless or yellowish shell, elliptical in ventral view; aperture relatively large with very irregular stony edge; upper lip sometimes with a kind of thickened tooth-shaped pronouncement, inner lip deflecting deeply within the test and having, in frontal view, the shape of a tongue with a rounded edge, shell covered with quartz particles, sometimes pretty large; average shell width $199 \mu \mathrm{m}$, average shell length $166 \mu \mathrm{m}$. Pores on the upper lip are not described, which make this species questionable to be considered within Bullinularia (same situation as in Bullinularia navicula). Following the decision made by Meisterfeld (2008) for Bullinularia navicula basing on the same reason we propose to tranfer this species into the genus Plagiopyxis.

II. A SHORT SYNONYMY AND NOMENCLATURE OF THE genus Bullinularia (BASED on Meisterfeld, 2008 WITH CHANGES)

\section{Bullinularia Deflandre, 1953}

- Bullinularia - (Deflandre, 1953), p. 127, 128, Fig. 90 A-E (replacement name)

Type species (by monotype): Bulinella indica Penard, 1907

Remark: Although Bulinella Penard, 1907 is a valid name it has not been in use during the last 90 years and for reasons of stability the name Bullinularia Deflandre, 1953 should be kept.

\section{Species included in Bullinularia:}

1. Bullinularia foissneri Meisterfeld, 2008

- Bullinularia foissneri - (Meisterfeld, 2008), p. 237, Figs 1-6.

2. Bullinularia gracilis Thomas, 1959

- Bullinula indica - (Penard, 1912), p.9-small elliptic form with shell width $120-125 \mu \mathrm{m}$;

- Bullinularia gracilis - (Thomas, 1959), p. 37, Figs 9-10;

- Bullinularia gracilis - (Golemansky, 1966), p. 219, Fig. 3;

- this paper. 1953

3. Bullinularia indica (Penard, 1907) Deflandre,

- Bullinula indica - (Penard, 1911), p. 225226, Pl. 22, Fig. 1 - medium size rather circular form with shell width $130-170 \mu \mathrm{m}$;

- Bullinula indica - (Penard, 1912), p. 1-9, Pl. 1, Fig. 2 - medium size rather circular form with shell width $130-170 \mu \mathrm{m}$;

- Bullinula indica - (Cash et al., 1919), p. 44-46, P1. 58, Figs 9-10;

- Bullinula indica var. minor - (Bartoš, 1940), p. 153 (nomen nudum);

- Bullinularia indica - (Deflandre, 1953), p. 127, 128, Fig. 90 A-E;

- Bullinularia gracilis - (Golemansky, 1968), p. $60-61$, Fig. 2 b; 


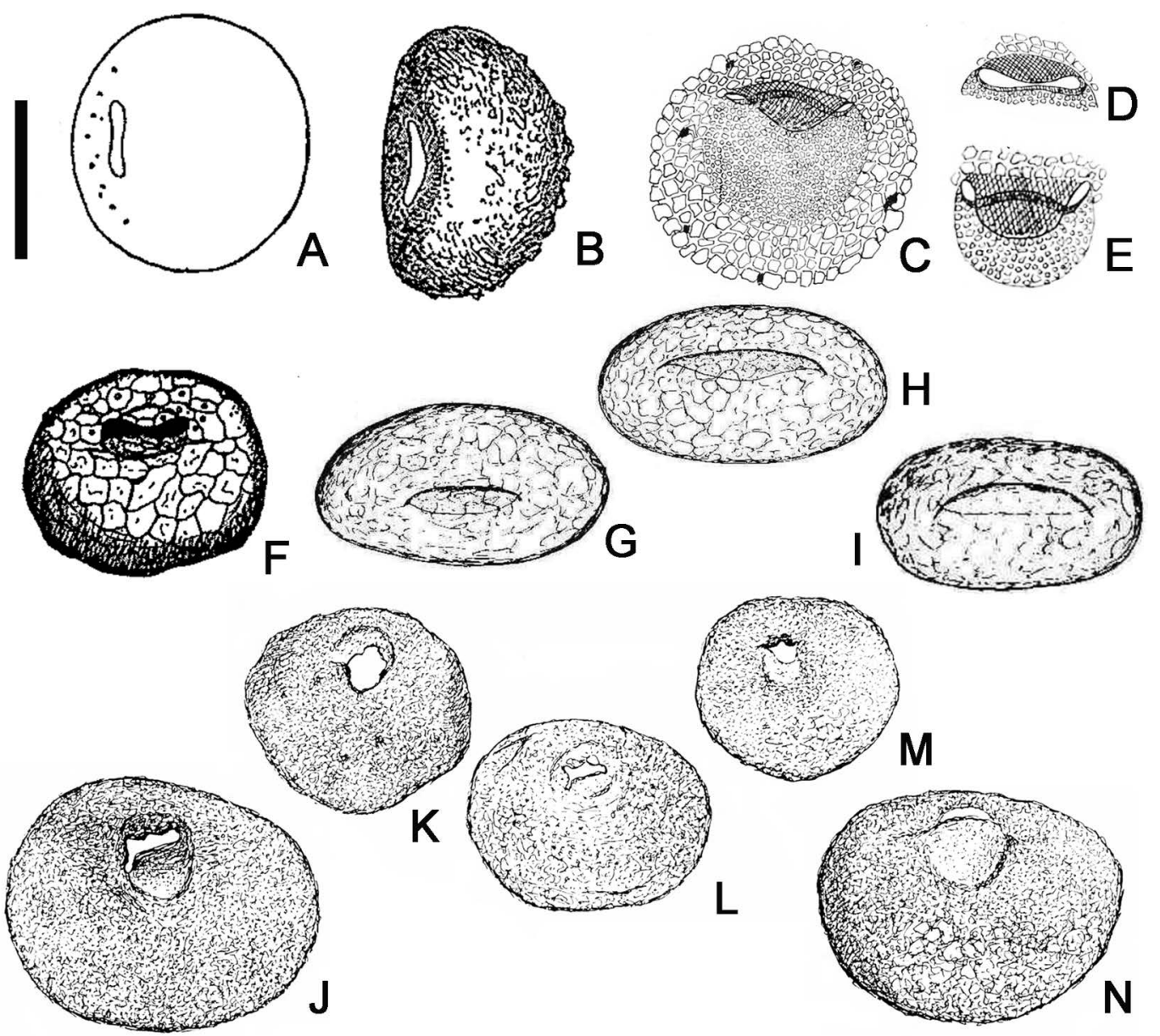

Fig. 11. Bullinularia minor $(\mathrm{A}-\mathrm{D})$, Bullinularia pulchella $(\mathrm{F})$, Bullinularia navicula $(\mathrm{G}-\mathrm{I})$, Bullinularia champi (J-O). A, C, F-I - Ventral view; B - aboral-ventral view; D, E - details of the apertural region. A, B - After Hoogenraad and de Groot, 1948; C-E - after Bartoš, 1963; F - after Schönborn, 1964; G-I - after Bonnet, 1979; J-N - after Thomas, 1997. Scale bar: $50 \mu \mathrm{m}$.

- Bullinularia devexa - (Coûteaux and Munsch, 1978), p. 396, Pl. I, Fig. 1, Pl. II, Figs 2, 4 (new synonym);

- Bullinularia indica - (Ogden and Hedley, 1980), p. 64-65, Pl. 21;

- Bullinularia gracilis - (Lüftenegger and Foissner, 1991), p. 2, Figs 1-8;

- Bullinularia indica - (Todorov and Bankov, 2019), p. 130-131, Fig. 60;

- this paper.

4. Bullinularia macroporum Bobrov et Mazei sp. nov.

- this paper.

5. Bullinularia maxima Bobrov et Mazei sp. nov.

- Bulinella indica - (Penard, 1907), p. 274-277, P1. 14, Figs 1-4;
- Bullinula indica - (Penard, 1911), p. 225-226 - large ellipsoidal form with shell width 190-250 $\mu \mathrm{m}$;

- Bullinula indica - (Penard, 1912), p. 1-9, Pl. 1, Fig. 1 - large ellipsoidal form with shell width $190-250 \mu \mathrm{m}$;

- this paper.

6. Bullinularia minor (Hoogenraad et de Groot, 1948) Deflandre, 1953

- Bullinula minor - (Hoogenraad and de Groot, 1948), p. 41-43, Fig. 17;

- Bullinularia minor - (Bartoš, 1963), p. 88, Fig. $2 \mathrm{~F}-\mathrm{H}$;

- Bullinularia pulchella - (Schцnborn, 1964), p. 110, Pl. 1, Fig. 11;

Remark: for synonymizing see Meisterfeld (2008), p. 239-240; 

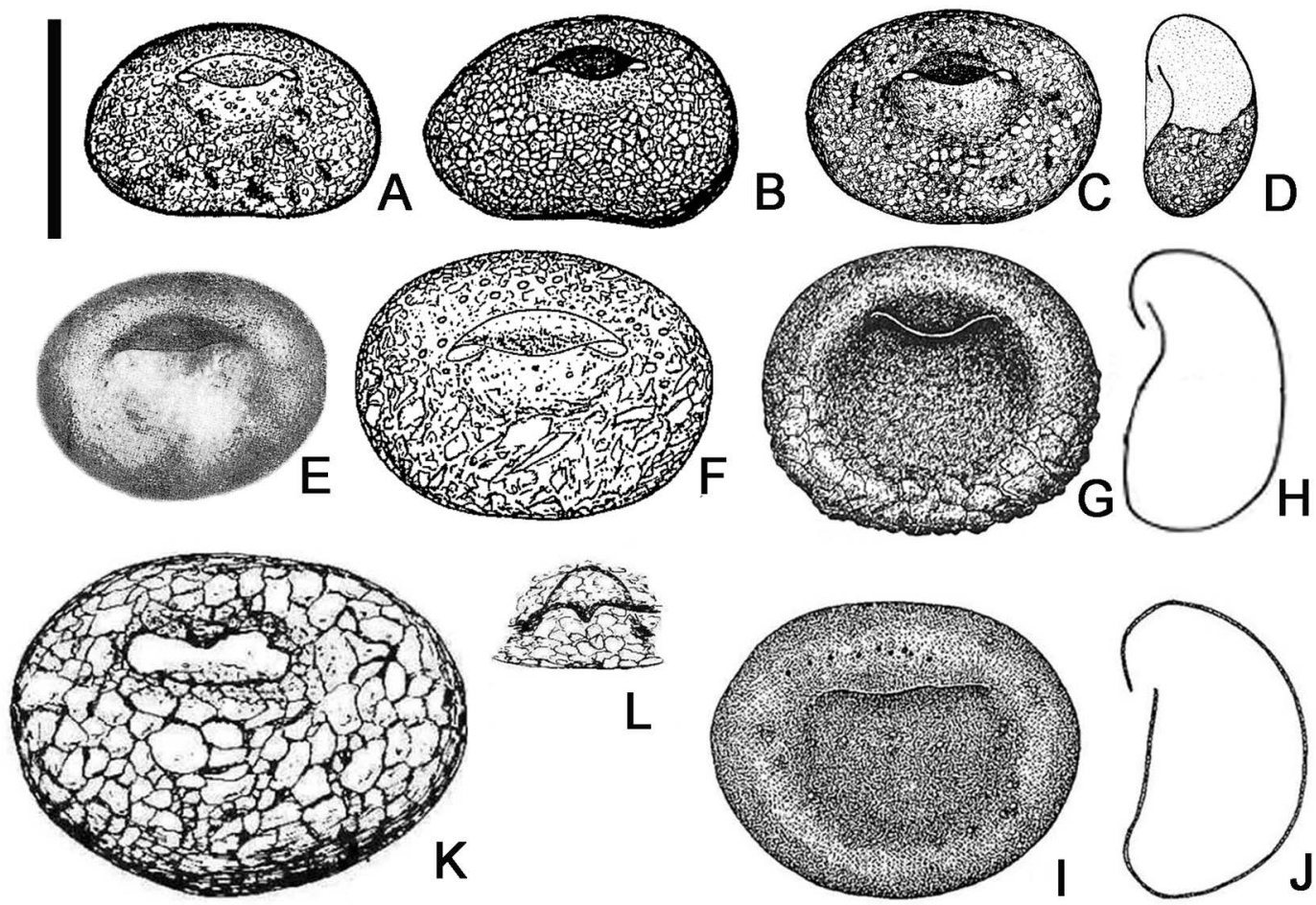

$\mathrm{K}$
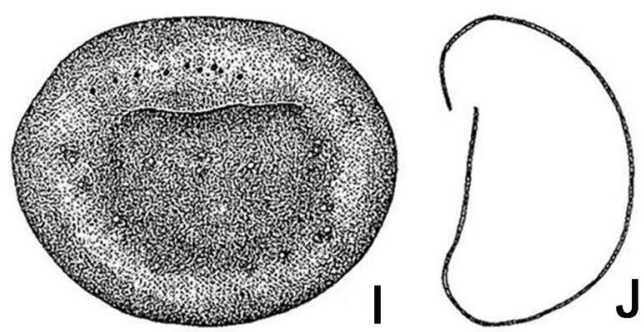

Fig. 12. Bullinularia gracilis (A-H), Bullinularia devexa $(\mathrm{I}, \mathrm{J})$, Bullinularia lithophora $(\mathrm{K}, \mathrm{L})$. A-C, E-F, G, I, $\mathrm{K}$ - Ventral view; D, H, J - lateral view; L - details of an aperture. A, B - After Thomas, 1959; C, D - after Bonnet and Thomas, 1960; E - after Golemansky, 1966; F - after Golemansky, 1968; G, H - after Lüftenegger and Foissner, 1991; I, J - after Coûteaux and Munsch, 1978; K, L - after Bonnet, 1974. Scale bar: $100 \mu \mathrm{m}$.

- Bullinularia champi - (Thomas, 1997), p. 30, Figs 1-6 (new synonym);

- this paper.

\section{Species misplaced in Bullinularia:}

Plagiopyxis navicula (Bonnet, 1979) Meisterfeld, 2008

- Bullinularia navicula - (Bonnet, 1979), p. 106, Figs A 1-3;

Remark: for foundation of transfer, see Meisterfeld (2008), p. 240.

Plagiopyxis lithophora (Bonnet, 1974) comb. nov.

- Bullinularia lithophora - (Bonnet, 1974), p. 283, Figs 1, 2;

Remark: for foundation of transfer, see above.

\section{KeY to THE SPECIES OF THE GENUS BULLINULARIA}

1. Shell length exceeds shell breadth (mean $1 / b$ ratio is 1.13), ventral face is bellied, apertural furrow is very conspicuous.

B. foissneri

1 '. Shell breadth exceeds shell length $(1 / \mathrm{b}$ ratio less than 1.0), ventral face is flat, depressed..........2

\section{Shell breadth is more than $190 \mu \mathrm{m}$}

B. maxima

2'. Shell breadth is between 130 and $190 \mu \mathrm{m} . . . .$.

2'. Shell breadth is less than $130 \mu \mathrm{m}$

B. indica

3. Shell length/shell breadth ratio is $0.70-0.80$; mean shell breadth is $120 \mu \mathrm{m}$; shell is chamois to brownish, transparent.

B. gracilis

3'. Shell length/shell breadth ratio is $0.85-0.95$

4. Pores on the dorsal lip are small $(2-3 \mu \mathrm{m})$ and numerous.

B. minor

4'. Pores on the dorsal lip are large $(7-8 \mu \mathrm{m})$ and few.....

B. macroporum 


\section{Acknowledgements}

The work was supported by the Russian Foundation for Basic Research (20-54-53017) - microscopic analysis and Russian Science Foundation (19-14-00102) - taxonomic synthesis.

We thank two anonymous reviewers for valuable comments.

\section{References}

Abakumov E.V., Rodina O.A., Eskov A.K. 2018. Humification and humic acid composition of suspended soil in oligotrophous environments in South Vietnam. Appl. Environ. Soil Sci. Article ID 1026237, P. 1-8.

Bamforth S. 2007. Protozoa from aboveground and ground soils of a tropical rain forest in Puerto Rico. Pedobiologia. 6, 515-525.

Bartoš E. 1938. Beitrage zur kenntnis des Baues der Schale von Bullinula indica Penard. Arch. Protistenk. 90, 348-353.

Bartoš E. 1940. Studien über die moosbewohnenden Rhizopoden der Karpaten. Arch. Protistenk. 94, 93-160.

Bartoš E. 1954. Kořenonožce radu Testacea. Vyd. Slov. Akad. Vied., Bratislava.

Bartoš E. 1963. Die Rhizopoden einiger Moosproben aus China. Acta Soc. Zool. Bohemoslov. 27, 85-96.

Bonnet L. 1974. Nouveaux thécamoebiens du sol. VII. Bull. Soc. Hist. Natur. Toulouse. 110, 283-290.

Bonnet L. 1979. Nouveaux thécamoebiens du sol. X. Bull. Soc. Hist. Natur. Toulouse. 115, 106-118.

Bonnet L. and Thomas R. 1960. Thécamoebiens du sol. In: Faune terrestre et d'eau douce des Pyrénées-Orientales, Supplement to Vie et Milieu. (Ed. Hermann). 5, 1-103.

Cash J., Wailes G.H. and Hopkinson J. 1919. The British freshwater Rhizopoda and Heliozoa. Vol. IV. Ray Society publication, London, Vol. 103.

Chardez D. 1965. Ecologie generale des Thecamoebiens. Bull. Inst. Agron. Stat. Rech. Gembloux. 33, 307-341.

Coûteaux M.-M. and Munsch A. 1978. Thécamoebiens de mangroves. Revue Ecol. Biol. Sol. $15,391-399$.

Deflandre G. 1953. Ordres des Testacealobosa (de Saedeleer, 1934), Testaceafilosa (de Saedeleer,
1934), Thalamia (Haeckel, 1862) ou Thécamoebiens (Rhizopoda Testacea). In: Traité de Zoologie, I, P. 97-148.

Delaine M., Bernard N., Gilbert D., Recourt Ph. and Armynot du Châtelet E. 2017. Origin and diversity of testate amoebae shell composition: Example of Bullinularia indica living in Sphagnum capillifolium. Eur. J. Protistol. 59, 14-25.

Delamare-Debouteville C. 1948. Étude quantitative du peuplement animal des sols suspendu et des epiphytes en forkt tropicale. C.R.Acad. Sci. 226, 1544-1546.

Geltzer Yu.G., Korganova G.A. and Alekseev D.A. 1995. Identification guide for soil testate amoebae (a practical guide). MSU Publishing house, Moscow (in Rissian).

Golemansky V. 1966. Étude de la faune rhizopodique (Rhizopoda, Testacea) dans le sol de la tourbière de Sadovo region de Plovdiv. Die Fauna Thrakiens 3, 217-230.

Golemansky V. 1968. Nouvelle contribution a la connaissance des Thécamoebiens (Rhizopoda, Testacea) en Yougoslavie. Acad. Bulg. Sci., Bull. Inst. Zool. (Sofia). 27, 57-63.

Heger T.J., Mitchell E.A.D. and Leander B.S. 2013. Holarctic phylogeography of the testate amoeba Hyalosphenia papilio (Amoebozoa: Arcellinida) reveals extensive genetic diversity explained more by environment than dispersal limitation. Mol. Ecol. 22, 5172-5184.

Hoogenraad H.R. and de Groot A.A. 1948. Thecamoebous moss rhizopods from New Zealand. Hydrobiologia. 1, 28-44.

Kosakyan A., Heger T.J., Leander B.S., Todorov M., Mitchell E.A.D. and Lara E. 2012. COI barcoding of nebelid testate amoebae (Amoebozoa: Arcellinida): extensive cryptic diversity and redefinition of the Hyalospheniidae Schultze. Protist. 163, 415-434.

Kosakyan A., Gomaa F., Lara E. and Lahr D.J. 2016. Current and future perspectives on the systematics, taxonomy and nomenclature of testate amoebae. Eur. J. Protistol. 55 (Part B), 105-117.

Krashevska V., Maraun M. and Scheu S. Microand macroscale changes in density and diversity of testate amoebae of tropical montane rain forests of Southern Ecuador. Acta Protozool. 49, 17-28.

Krashevska V., Tsyganov A., Esaulov A., Mazei Yu., Hapsari K.A., Saad A., Subiham S., Behling H. and Biagioni S. 2020. Testate amoebae species and trait-based transfer functions for reconstruction of hydrological regime in tropical peatland of Cent- 
ral Sumatra, Indonesia. Front. Ecol. Evol. doi: 10.3389 /fevo.2020.00225.

Lüftenegger G. and Foissner W. 1991. Morphology and biometry of twelve soil testate amoebae (Protozoa, Rhizopoda) from Australia, Africa and Austria. Bull. Brit. Mus. (Nat. Hist.), Zool. Ser. 57, 1-16.

Mazei Yu. and Belyakova O. 2011. Testate amoebae community structure in the moss biotopes of streams. Biol. Bull. 38, 1008-1013.

Mazei Yu., Belyakova O., Coppellotti O. and Payne R. 2016. Testate amoeba communities of epilithic mosses and lichens: new data from Russia, Switzerland and Italy. Acta Protozool. 55, 51-57.

Mazei Yu., Belyakova O., Trulova A., Guidolin L. and Coppellotti O. 2012. Testate amoebae communities from caves of some territories in European Russia and North-Eastern Italy. Protistology. 7, 42-50.

Mazei Yu., Chernyshov V., Tsyganov A. and Payne R. 2015. Testing the effect of refrigerated storage on testate amoeba samples. Microb. Ecol. 70, 861-864.

Mazei Yu. and Tsyganov A. 2006. Freshwater testate amoebae. KMK, Moscow (in Rissian).

Meisterfeld R. 2008. Bullinularia foissneri nov. spec. (Amoebozoa, Arcellinida) from Australia and synopsis of the genus Bullinularia. Denisia. 23, 235-241.

Ogden C.G. and Hedley R.H. 1980. An atlas of freshwater testate amoebae. Oxford University Press, London.

Paoletti M., Taylor R., Stinner B., Stinner D. and Benzing D. 1991. Diversity of soil fauna in the canopy and forest floor of a Venezuelan cloud forest. J. Trop. Ecol. 7, 373-383.
Payne R.J. 2013. Seven reasons why protists make useful bioindicators. Acta Protozool. 52, 105-113.

Payne R., Belyakova O. and Mazei Yu. 2015. Community structure and environmental controls on forest epiphyte testate amoeba communities from European Russia. Eur. J. Protistol. 51, 450-459.

Penard E. 1907. On some rhizopods from the Sikkim Himalaya. J. Roy. Microscop. Soc., 274278 + Plate XIV.

Penard E. 1911. British Antarctic Expedition 1907-1909. Reports of the scientific investigations. Vol. 1. Biology (Ed. J. Murray), Part VI. Sarcodina. Rhizopodes d'eau douce, 203-257 + Plates XXIIXXIII.

Penard E. 1912. Notes sur quelques Sarcodinés. Troisièm partie. Rev Suisse Zool. 20, 1-29+ Plates $1,2$.

Potapov A., Bonnier R., Sandmann D., Wang S., Widyastuti R., Scheu S. and Krashevska V. 2020. Aboveground soil supports high levels of biological activity in oil palm plantations. Front. Ecol. Envir. 18(4), 181-187.

Schönborn W. 1964. Bodenbewohnende Testaceen aus Deutschland. I. Untersuchungen im Naturschutzgebiet Serrahn (Mecklenburg). Limnologica 2, 105-122.

Thomas R. 1959. Les Thécamoebiens muscicoles et terricoles: notions d'écologie générale et comparative. Proc Soc. Linn. Bordeaux, 98, 27-53.

Thomas R. 1997. Faune rhizopodique du Népal (Thécamœbiens). Bull. Soc. Linn. Bordeaux. 25, 25-30.

Todorov M. and Bankov N. 2019. An atlas of Sphagnum-dwelling testate amoebae in Bulgaria. Pensoft, Sofia.

Address for correspondence: Yuri Mazei. Lomonosov Moscow State University, Leninskiye gory 1, 119991, Moscow, Russia; e-mail: yurimazei@mail.ru 